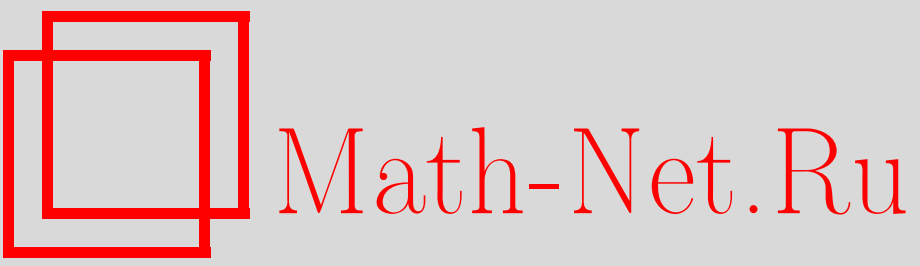

Информационное сообщение о симпозиуме CTCrypt'2017, Mameм. вопр. криптогр., 2018, том 9, выпуск 2, 5-6

DOI: https://doi.org/10.4213/mvk259

Использование Общероссийского математического портала Math-Net.Ru подразумевает, что вы прочитали и согласны с пользовательским соглашением

http://www.mathnet.ru/rus/agreement

Параметры загрузки:

IP : 54.196 .121 .252

26 апреля 2023 г., 18:18:22 
МАТЕМАТИЧЕСКИЕ ВОПРОСЫ КРИПТОГРАФИИ

2018 T. 9 № 2 C. 5-6

\section{Информационное сообщение о симпозиуме CTCrypt'2017}

С 5 по 7 июня 2017 г. в поселке Репино (г. Санкт-Петербург) прошел 6-й международный симпозиум «Современные тенденции в криптографии» (CTCRypt'2017), посвященный исследованиям в теоретических и прикладных областях криптографии.

На симпозиуме выступили зарубежные приглашенные докладчики ЖанФилипп Омассон (Швейцария) с докладом «Криптография сегодня» и Грегор Леандер (Германия) с докладом «Структурные атаки на блочные шифры». Живейший интерес аудитории вызвал доклад российского историка криптографии Бориса Столпакова «Исторические свидетельства зарождения и становления российской криптографии (XVI-XVII вв.)». На алгебраической секции симпозиума Василий Шишкин в докладе «Наследие Алексея Кузьмина» рассказал об основных направлениях научных исследований одного из основателей симпозиума CTCrypt, выдающегося российского алгебраиста Алексея Сергеевича Кузьмина.

На секции «Квантовая криптография в России: от теории к практике» ученые из Московского государственного университета имени М. В. Ломоносова, Санкт-Петербургского национального университета информационных технологий, механики и оптики и Российского квантового центра выступили с докладами о последних отечественных достижениях в области теоретической квантовой криптографии, а также рассказали об опыте создания реально действующих квантовых криптографических систем.

Секция «Блокчейн в России: ожидания рынка» в отличие от множества проводимых в настоящее время конференций была посвящена наиболее острым и проблемным вопросам, возникающим перед исследователями и разработчиками при реализации систем, использующих широко обсуждаемую технологию блокчейн.

Citation: Mathematical Aspects of Cryptography, 2018, v. 9, № 2, p. 5-6 (Russian)

(C) Академия криптографии Российской Федерации, 2018 г. 
По результатам рецензирования международным программным комитетом в программу симпозиума было отобрано 18 работ, часть из которых рекомендована к публикации в журнале «Математические вопросы криптографии». В соответствии с правилами симпозиума статьи публикуются на английском языке с аннотациями на русском языке.

Оргкомитет Симпозиума 